de Direito Processual

\title{
Por uma Concepção Funcional da Jurisdição
}

\author{
For a Functional Design of Jurisdiction
}

Rosalina Freitas Martins de Sousa'

${ }^{1}$ Universidade Federal da Pernambuco - UFPE, Brasil

\section{Resumo}

O ensaio defende a necessidade de se adotar uma concepção mais funcional da jurisdição. Para tanto, propõe uma releitura do princípio da inafastabilidade, previsto no art. $5^{\circ}, \mathrm{XXXV}$, da CF/88. A interpretação ampla que tem sido conferida ao mencionado dispositivo constitucional vem funcionando como permissivo para que toda e qualquer questão seja apreciada pelas vias judiciárias, mesmo quando se sabe que o Poder Judiciário não tem expertise para julgar determinadas matérias. Ao se admitir o exercício da função jurisdicional por outros órgãos, ainda que não vinculados à estrutura do Poder Judiciário, o princípio da inafastabilidade assume uma fisionomia prestacional, não simples garantia passiva, mas uma obrigação a ser ativamente ofertada pelo Estado, que deve considerar o aspecto da eficiência do serviço a ser ofertado à sociedade.

Palavras-chave: Poder judiciário; Inafastabilidade; Função jurisdicional; Eficiência

\begin{abstract}
The present essay defends the need to adopt a more functional conception to jurisdiction. To this end, it proposes a re-reading of the principle of non-feasibility, provided for in art. $5, X X X V$, of $C F / 88$. The broad interpretation that has been given to the aforementioned constitutional provision has been operating as permissive for any and all issues to be assessed through the judicial channels, even when it is known that the Judiciary does not have the expertise to judge certain matters. When admitting the exercise of the jurisdictional function by other bodies, even if not related to the structure of the Judiciary, the principle of non-enforceability assumes a rendering of benefits, not merely a passive guarantee, but an obligation to be actively offered by the State, which must consider the aspect of the efficiency of the service to be offered to society.
\end{abstract}

Keywords: Judiciary; Unfeasibility; Jurisdictional Function; Efficiency

\section{Introdução: o poder judiciário e o exercício da função jurisdicional}

Além de investigar sobre temas fundamentais da ciência processual, José Joaquim Calmon de Passos também muito refletiu a respeito do Poder Judiciário e do exercício da função jurisdicional ${ }^{1}$. Em inúmeros ensaios, entrevistas e também em vários livros de sua autoria, a exemplo daquele intitulado "Direito, poder, justiça e processo - julgando os que nos julgam” (o título da obra já diz muito!), o grande jurista cuidou de analisar com profundidade a temática, sempre com o viés crítico que lhe era peculiar.

1 "Falar sobre crise do Poder Judiciário é algo que comporta mais de uma abordagem. É possível inseri-la na crise mais ampla do próprio modelo de Estado em que ele se insere. Pode, outrossim, configurar-se como uma crise que lhe seja específica, localizada no processo constitucional de produção jurisdicional do direito ou na institucionalização dos agentes políticos por ele responsáveis, como pode simplesmente ser um problema menor, relacionado com os procedimentos adotados naquele processo constitucional já referido”. PASSOS, J. J. Calmon de. A crise do Poder Judiciário e as reformas instrumentais: avanços e retrocessos. Revista Eletrônica sobre a Reforma do Estado. Bahia, n. 5, p. 01, março/abril/maio 2006. Disponível a partir de: <http://www.direitodoestado.com.br $>$. 
O presente artigo, em certa medida, se conecta e encontra apoio nas ideias lançadas por Calmon de Passos, já que analisa a possibilidade do exercício da função jurisdicional por outros órgãos, ainda que não vinculados à estrutura do Poder Judiciário. Na verdade, o ensaio se propõe a demonstrar, ainda que com uma abordagem bem diferente daquela realizada pelo pensador baiano, que é preciso - e também possível - promover uma releitura do princípio da inafastabilidade, previsto no art. $5^{\circ}, \mathrm{XXXV}$, da $\mathrm{CF} / 88$, sobretudo em razão das mudanças operadas no contexto social e da necessidade de o Estado garantir a eficiência na prestação dos serviços.

De acordo com o art. $5^{\circ}, \mathrm{XXXV}$, da CF/88, "a lei não excluirá da apreciação do Poder Judiciário lesão ou ameaça a direito". A interpretação ampla que tem sido conferida ao referido dispositivo constitucional vem funcionando como permissivo para que toda e qualquer questão seja apreciada pelas vias judiciárias, mesmo quando se sabe que o Poder Judiciário não detém expertise para julgar determinadas matérias, que exigem um conhecimento muito técnico e específico².

Nesse sentido, entende-se ser chegado o momento de se adotar uma concepção mais funcional da jurisdição, de modo a aumentar a eficiência do Estado, organizando-o da maneira mais adequada para o desempenho de suas atribuições.

Ao se admitir o exercício da função jurisdicional por outros órgãos, ainda que não vinculados à estrutura do Poder Judiciário, aos quais seria atribuída competência para decidir, em razão de sua aptidão decisória, o princípio da inafastabilidade passaria a assumir uma feição prestacional, não simples garantia passiva, mas uma obrigação a ser ativamente ofertada pelo Estado, que deve considerar o aspecto da eficiência do serviço a ser ofertado à sociedade.

\section{Do poder à função. A necessidade de se aumentar a eficiência do estado}

É comum e até corriqueiro se associar, quase que automaticamente, o exercício da jurisdição ao Poder Judiciário ${ }^{3}$.

Pode-se dizer que essa visão a respeito da atividade jurisdicional, concentrada no âmbito do Poder Judiciário, é uma herança da teoria da separação dos poderes nas suas primeiras aplicações, que tendia para a unidade orgânica, de modo a concentrar a jurisdição nas vias judiciárias ${ }^{4}$. É também possível sustentar que essa compreensão ainda permanece em razão do destaque que se dá ao estudo das chamadas funções típicas (em detrimento das atípicas) de cada um dos Poderes.

Entretanto, considerando as mudanças operadas no Estado e na sociedade ao longo dos anos, não mais se sustenta uma compreensão clássica acerca da teoria da separação de poderes, que resultou

2 Calmon de Passos afirmava: "a juridicização de todos os conflitos sociais gera uma sobrecarga para o Poder Judiciário e um esforço de mediação que escapa ao seu saber técnico e especializado”. PASSOS, J. J. Calmon. Revisitando o Direito, o Poder, a Justiça e o Processo. Reflexões de um jurista que trafega na contramão. Bahia: JusPodivm, 2013 , p. 207.

3 O reconhecimento da natureza jurisdicional da arbitragem, além de corroborar a ideia de que a função jurisdicional não se confina nas vias judiciárias, deixa claro que o Poder Judiciário não é o único centro de resolução de conflitos. Defendendo a natureza jurisdicional da arbitragem: CARMONA, Carlos Alberto. A arbitragem no processo civil brasileiro. São Paulo: Malheiros, 1993; CUNHA, Leonardo José Carneiro da. Jurisdição e competência. São Paulo: Revista dos Tribunais, 2008, 79; DIDIER JR. Fredie. Curso de Direito Processual Civil. Introdução ao direito processual civil, parte geral e processo de conhecimento. 17a ed. Bahia: JusPodivm, 2015, p. 172; DINAMARCO, Cândido Rangel. Instituições de direito processual civil. vol. I, 8. ed, São Paulo: Malheiros, 2016, p. 454; GAJARDONI, Fernando da Fonseca. Aspectos fundamentais de processo arbitral e pontos de contato com a jurisdição estatal. Revista de Processo: São Paulo, n. 106, p. 190, jul. 2002. Na jurisprudência, considerando a arbitragem jurisdição: SUPERIOR TRIBUNAL DE JUSTIÇA. 2a Seção. Conflito de competência no 111.230-DF. Relator: Ministra NANCY ANDRIGHI. Decisão por maioria. Brasília, 08.05.2013. DJ de 03.04.2014. Disponível a partir de: <http:www.stj.jus.br>. Acesso em: 21 ago. 2016. Ainda há outro julgado do STJ no mesmo sentido: SUPERIOR TRIBUNAL DE JUSTIÇA. 2ª Seção. Conflito de competência no 146.939/PA. Relator: Ministro Marco Aurélio Bellizze. Decisão unânime. Brasília, 23.11.2016. DJ de 30.11.2016. Disponível a partir de: <http:www.stj.jus.br>. Acesso em: 21 ago. 2016.

4 Giuseppe Chiovenda, era peremptório ao afirmar que: "A teoria da divisão dos poderes, em suas primeiras aplicações em França, foi entendida em sentido rígido e mecânico: assim, a cada órgão deveria corresponder uma só função e lhe era defeso ingerir na atividade do outro, sequer para sindicá-la ou corrigi-la”. CHIOVENDA, Giuseppe. Instituições de direito processual civil. Tradução: J. Guimarães Menegale. 2. ed. São Paulo: Saraiva, 1965, vol. 2, p. 8. 
numa divisão em compartimentos estanques. Não se pode continuar a pensar a separação de poderes com os fundamentos de uma sociedade que não mais existe.

Ao longo dos anos, foram se ampliando os espaços de intersecção e interferência entre os poderes estatais. Passou-se a conviver com uma permissão, cada mais alargada, de exercício de funções atípicas, além daquelas que cabiam ordinária e tipicamente a cada um dos Poderes. Não se pode olvidar, ainda, que durante todo o fluxo evolutivo da história, foram surgindo novos órgãos e centros de poder autônomo, com competências técnicas e específicas, sobretudo diante da necessidade de o Estado garantir a eficiência na prestação dos serviços.

Toda essa transformação, inegavelmente, fez com que o princípio da separação dos poderes perdesse a configuração clássica de outrora. É por isso que se diz que o princípio da separação dos poderes, na atualidade, "deve assumir uma "noção menos mistificadora e mais pragmática"”

A ideia de separação de poderes, na verdade, representa, uma divisão de órgãos ou separação relativa de órgãos para exercitarem as distintas funções do Estado: uma coisa é o Poder do Estado, uno e indivisível ${ }^{6}$; outra coisa é a diversidade de funções, com a correspondente diversidade de órgãos ${ }^{7}$. $\mathrm{O}$ poder do Estado divide-se e se encerra num sistema de competências delimitadas ${ }^{8}$.

A relação entre poder e função permite compreender o próprio papel desempenhado pelo Estado na vida social, como bem adverte Dalmo de Abreu Dallari:

De fato, quando se pretende desconcentrar o poder, atribuindo o seu exercício a vários órgãos, a preocupação maior é a defesa da liberdade dos indivíduos, pois, quanto maior for a concentração do poder, maior será o risco de um governo ditatorial. Diferentemente, quando se ignora o aspecto do poder para se cuidar das funções, o que se procura é aumentar a eficiência do Estado, organizando-o da maneira mais adequada para o desempenho de suas atribuições ${ }^{9}$

Essa compreensão funcional da separação de poderes está justamente voltada para o aumento da eficiência do Estado, devendo o legislador ficar atento no momento em que for definir as competências dos órgãos para o julgamento das diversas matérias no âmbito estatal, sobretudo aquelas que envolvem expertise no seu trato.

Especificamente no tocante à definição das competências sobre apreciação de certas matérias, se administrativa ou judicial, parece-nos que é necessário considerar que a eficiência é uma imposição constitucional a todos os poderes, pois é princípio da Administração Pública, e deve ser levada em conta na definição das competências dos órgãos públicos para o julgamento das diversas matérias no âmbito estatal, a fim de evitar que haja o dispêndio desnecessário de atividades administrativas que terão pouca ou nenhuma valia, na medida em que poderão ser integralmente desconstituídas por atividade do próprio Poder Público $[\ldots]^{10}$.

$5 \quad$ KRELL, Andreas J. Leis de normas gerais, regulamentação do poder executivo e cooperação intergovernamental em tempos de reforma federativa. Belo Horizonte: Forum, 2008, p. 71-72.

6 DALLARI, Dalmo de Abreu. Elementos de teoria geral do Estado. 33. ed. São Paulo: Saraiva, 2016 , p. 214.

7 ROCHA, José de Albuquerque. Teoria geral do processo. 10. ed. São Paulo: Atlas, 2009, p. 63; GORDILLO, Agustin. Princípios gerais de direito público. São Paulo: Revista dos Tribunais, 1977, p. 110; DANTAS, Ivo. Teoria geral do Estado. 3. ed. Curitiba: Juruá, 2016, p. 307; DALLARI, Dalmo de Abreu. Elementos de teoria geral do Estado. 33. ed. São Paulo: Saraiva, 2016, p. 213; SANTOS, Moacyr Amaral. Primeiras linhas de direito processual civil. Processo de conhecimento, 25 ed. São Paulo: Saraiva, 2007, p. 83; CARNEIRO, Athos Gusmão. Jurisdição e competência. 15. ed. São Paulo: Saraiva, 2007, p. 22-24. CUNHA, Leonardo José Carneiro da. Jurisdição e competência. São Paulo: Revista dos Tribunais, 2008, 41; DINAMARCO, Cândido Rangel. Instituições de direito processual civil. Vol. I, 8. ed, São Paulo: Malheiros, 2016, p. 453; CINTRA, Antonio Carlos de Araújo; DINAMARCO, Cândido Rangel; GRINOVER, Ada Pellegrini. Teoria geral do processo. 23a ed., São Paulo: Malheiros, 2007, p. 172.

8 OLIVEIRA, Carlos Alberto Alvaro de. Do formalismo no processo civil: proposta de um formalismo-valorativo. 4. ed. São Paulo: Saraiva, 2010, p. 88.

9 DALLARI, Dalmo de Abreu. Elementos de teoria geral do Estado. 33. ed. São Paulo: Saraiva, 2016 , p. 214.

10 ZUFELATO, Camilo. Reflexões acerca da sindicabilidade de certas decisões administrativas e a noção de inafastabilidade da tutela jurisdicional no contexto atual das competências estatais. In: ZUFELATO, Camilo; YARSHELL, Flávio Luiz (orgs.). 40 anos da teoria geral do processo no Brasil: passado, presente e futuro. São Paulo: Malheiros, 2013, p. 172. 
Parece ter sido essa a ideia quando o legislador fixou, por exemplo, a competência do Tribunal de Contas para "julgar as contas dos administradores e demais responsáveis por dinheiros, bens e valores públicos da administração direta e indireta, incluídas as fundações e sociedades instituídas e mantidas pelo Poder Público federal” (CF/88, art. 71, II).

O Conselho Nacional de Justiça (CNJ), órgão administrativo vinculado à estrutura do Poder Judiciário, tem competência para julgar processos administrativos relacionados ao Poder Judiciário e seus serviços. O Tribunal Marítimo, por sua vez, é encarregado de julgar os acidentes e fatos da navegação ${ }^{11}$. O Conselho Administrativo de Defesa Econômica (CADE) exerce função jurisdicional nos casos relacionados ao direito da concorrência. Todos esses órgãos administrativos, inegavelmente, exercem função jurisdicional, e, mais, lidam com matérias que exigem certa expertise, que fogem do universo ordinário do Poder Judiciário.

Mas é difícil imaginar uma concepção mais funcional da jurisdição quando se sabe que o Poder Judiciário acaba sendo o natural escoradouro de toda e qualquer controvérsia, em razão da interpretação ampla que se dá ao art. 5º, XXXV, da CF/88. Cumpre, então, analisar o chamado princípio da inafastabilidade.

\section{O princípio da inafastabilidade e a sua previsão expressa no texto constitucional de 1946. O reconhecimento de que a Constituição de 1946 nasceu de "costas para o futuro"}

Analisando as Constituições brasileiras (1824, 1891, 1934, 1937, 1946, 1967 e 1988), verifica-se que o princípio da inafastabilidade do controle jurisdicional somente veio a ser expressamente inserido no sistema normativo a partir da Constituição de 1946 (art. 141, § 4º), com a seguinte redação: "A lei não poderá excluir da apreciação do Poder Judiciário qualquer lesão de direito individual ${ }^{12}$ ".

Em que pese ter sido consagrado de forma expressa, pela primeira vez, na Constituição brasileira de 1946, afirmou Celso Ribeiro Bastos ${ }^{13}$, apoiado na lição de Pontes de Miranda, que o princípio da inafastabilidade da jurisdição já poderia ser tido como presente, ainda que implicitamente, desde a Constituição de 1891, já que o Brasil aderiu à teoria da tripartição de Poderes, em Executivo, Legislativo e Judiciário.

Com efeito, foi a partir da sistemática implantada na Constituição de 1891 que o Brasil aderiu, estruturalmente, à teoria tripartite, inspirando-se na Constituição americana e também nas ideias do iluminismo francês ${ }^{14}$. De qualquer forma, somente a partir da Constituição de 1946 é que o princípio da inafastabilidade do controle jurisdicional veio expressamente tratado no texto constitucional, nos termos do art. 141, $\$ 4^{\circ}$, já acima citado.

11 É nesse sentido o disposto no art. $1^{\circ}$ da Lei $n^{\circ}$ 2.180/1954: O Tribunal Marítimo, com jurisdição em todo o território nacional, órgão, autônomo, auxiliar do Poder Judiciário, vinculado ao Ministério da Marinha no que se refere ao provimento de pessoal militar e de recursos orçamentários para pessoal e material destinados ao seu funcionamento, tem como atribuições julgar os acidentes e fatos da navegação marítima, fluvial e lacustre e as questões relacionadas com tal atividade, especificadas nesta Lei.

12 O termo individual, hoje suprimido do dispositivo constitucional, gerava a equivocada impressão de que somente as pessoas, individualmente, poderiam socorrer-se da jurisdição estatal. A melhor interpretação, contudo, sempre valeuse do conteúdo genérico dessa expressão, reconhecendo que o direito de ação é garantido a todos, indistintamente, compreendendo as pessoas físicas, as jurídicas e os entes despersonalizados. A esse respeito, NETO, Zaidem Garaige. O princípio da inafastabilidade do controle jurisdicional, São Paulo: Revista dos Tribunais, 2006, p. 39-41.

13 BASTOS, Celso Ribeiro. Curso de Direito Constitucional, 18 ed. São Paulo: Saraiva, 1997, p. 197.

14 Cabe lembrar que a primeira Constituição brasileira - a de 1824 - previa quatro poderes: o Poder Legislativo, o Poder Moderador, o Poder Executivo e o Poder Judicial. O Poder Moderador, concentrado na pessoa do Imperador, e que, justamente por isso, permitia a concentração de poderes nas mãos do Imperador, era a chave da organização política. Segundo Paulo Bonavides e Paes de Andrade, o Poder Moderador da Constituição do Império é a constitucionalização do absolutismo, se é que isto é possível. BONAVIDES, Paulo; ANDRADE, Paes. História constitucional do Brasil. Rio de Janeiro: Paz e Terra, 1991, p. 95. 
Após o golpe militar de 1964, seguiu-se a Constituição de 1967, que cuidou de reproduzir, no capítulo destinado aos direitos e garantias individuais, especificamente no seu art. $150, \S 4^{\circ}$, o princípio da inafastabilidade do controle jurisdicional, tal como previsto na Constituição de $1946^{15}$.

Entretanto, apesar da previsão, o Presidente da República da época, rompendo com a ordem constitucional vigente, através do Ato Institucional no 5, de 1968, especificamente através do seu art. $11^{16}$, excluiu do exame do Poder Judiciário a apreciação dos atos administrativos baseados nos atos institucionais do Golpe Militar de 1964, como também dos seus respectivos efeitos. Seguiram-se dezenas de outros atos institucionais, atos complementares, além de decretos-leis, até que, em dezembro de 1969, veio a primeira Emenda à Constituição de 1967, para alguns uma nova Constituição ${ }^{17}$.

Como se vê, mesmo violando frontalmente a Constituição de 1967, o Ato Institucional n $5^{\circ}$ acabou sendo constitucionalizado em razão da Emenda Constitucional noำ 1, de 1969, já que ficou estabelecido, em seus arts. 181 e 182, que seriam excluídos da apreciação do Poder Judiciário todos os atos praticados pelo comando da Revolução de 1964. Disposições dessa natureza, no entanto, não foram repetidas na Constituição de $1988^{18}$.

Com efeito, os princípios fundamentais constantes do texto constitucional refletem a reação de movimentos sociais frente ao abuso acometido no período ditatorial, marcado pela suspensão do pleno exercício de direitos fundamentais ${ }^{19}$. Eis, então, a atual redação do art. $5^{\circ}$, XXXV da CF/88: "a lei não excluirá da apreciação do Poder Judiciário lesão ou ameaça a direito" ${ }^{20}$.

Vigora, portanto, implicitamente desde a Constituição de 1891 e explicitamente a partir da Constituição de 1946, com contornos muito próximos aos atuais (CF/88, art. $5^{\circ}$, XXXV), o princípio da inafastabilidade do controle jurisdicional, em que pese ter havido momentos históricos em que o acesso ao Poder Judiciário, embora insculpido na ordem constitucional, tenha sido limitado ou mesmo impedido por um Estado totalitário ${ }^{21}$.

Mas há uma questão relevante em todo esse histórico que não pode passar despercebida. Já se afirmou que a Constituição de 1946 foi inspirada nas ideias liberais da Constituição de $1891^{22}$. É

15 "[...] de maneira geral, as opiniões sobre a Carta de 1967 chocavam-se com uma comum realidade: alguns textos formalmente liberais colidiram com a realidade ditatorial e vários dispositivos autoritários, permitindo ao Executivo sobrepor-se aos Poderes Legislativo e Judiciário”. BONAVIDES, Paulo; ANDRADE, Paes. História constitucional do Brasil. Rio de Janeiro: Paz e Terra, 1991, p. 442.

16 O art. 11 do Ato Institucional n $5 / 68$ previa que "Excluem-se de qualquer apreciação judicial todos os atos praticados de acordo com este Ato Institucional e seus Atos Complementares, bem como os respectivos efeitos".

17 "Teórica e tecnicamente, não se tratou de emenda, mas de nova constituição. A emenda só serviu como mecanismo de outorga, uma vez que verdadeiramente se promulgou texto integralmente reformado, a começar pela denominação que se lhe deu: Constituição da República Federativa do Brasil, enquanto a de 1967 se chamava apenas Constituição do Brasil. [...] Se convocava a Constituinte para elaborar Constituição nova que substituiria a que estava em vigor por certo não tem a natureza de emenda constitucional, pois tem precisamente sentido de manter a Constituição emendada. Se visava destruir esta, não pode ser tida como emenda, mas como ato político" SILVA, José Afonso da. Curso de direito constitucional positivo, 22. ed. São Paulo: Malheiros, 2002, p. 89.

18 NERY JÚNIOR, Nelson. Princípios do processo na Constituição Federal. Processo civil, penal e administrativo. 11. ed. São Paulo: Revista dos Tribunais, 2013, p. 186.

19 "A Constituição de 1988 foi o marco zero de um recomeço, da perspectiva de uma nova história. Sem as velhas utopias, sem certezas ambiciosas, com o caminho a ser feito ao andar. Mas com uma carga de esperança e um lastro de legitimidade sem precedentes, desde que tudo começou. E uma novidade. Tardiamente, o povo ingressou na trajetória política brasileira, como protagonista do processo, ao lado da velha aristocracia e da burguesia emergente”. BARROSO, Luís Roberto; BARCELLOS, Ana Paula. O começo da história. A nova interpretação constitucional e o papel dos princípios no direito brasileiro. Rio de Janeiro: Revista da EMERJ, n. 23, p. 26, 2003.

20 Há ainda outra nota digna de destaque: a Constituição de 1967 previa expressamente a proteção a direito individual. Era esse o termo constante do texto. A CF / 1988 não repetiu o vocábulo, mas, ao contrário, ao fazer referência simplesmente a "lesão ou ameaça a direito", com a retirada do termo "individual”, consagrou o legislador constituinte a tutela dos direitos coletivos. Por outro lado, com a inclusão da palavra ameaça, inexistente na ordem anterior, o legislador constituinte acabou por constitucionalizar a tutela preventiva, a tutela de urgência, a tutela contra o perigo.

21 NERY JÚNIOR, Nelson. Princípios do processo na Constituição Federal. Processo civil, penal e administrativo. 11. ed. São Paulo: Revista dos Tribunais, 2013, p. 186.

22 LENZA, Pedro. Direito constitucional esquematizado. 19 ed. São Paulo: Saraiva, 2015, p. 140. 
justamente pelo fato de ter se voltado à fonte formal do passado que se afirma que a Constituição de 1946 nasceu de costas para o futuro ${ }^{23}$.

Diante dessa relação com a Constituição de 1891 - a primeira constituição brasileira, repita-se, a acolher a teoria de três poderes - não é insólito dizer que o princípio da inafastabilidade do controle jurisdicional, constante do texto de 1946 (praticamente reproduzido pela CF/88), estava absolutamente conectado com a ideia de que a jurisdição era prestada pelo Poder Judiciário.

Ainda que a Constituição de 1891, que inspirou o texto de 46, já admitisse o exercício da função jurisdicional por outros órgãos não vinculados à estrutura do Poder Judiciário - tanto assim que previa o julgamento dos crimes de responsabilidade pelo Legislativo ${ }^{24}$ - parece natural admitir que, naquela época, tendia-se para a unidade orgânica, de modo a concentrar a função jurisdicional nas vias judiciárias, sobretudo considerando a inspiração nas ideias oriundas do ciclo liberal francês ${ }^{25}$.

Reconhece-se que a inserção do art. 5, XXXV, no bojo da Constituição Federal de 1988 considerada uma conquista histórica ${ }^{26}$ - tem uma justificativa ligada ao regime ditatorial que o Brasil havia acabado de superar quando da promulgação da $\mathrm{CF} / 88$, de forma que deixar expresso o recurso ao Poder Judiciário como bastião da salvaguarda de direitos era realmente relevante e oportuno.

No entanto, conforme analisado no item acima, diante das mudanças operadas no Estado e na sociedade, e, mais, diante da técnica especial que, em muitos assuntos, torna impróprio o conhecimento do juiz togado para resolvê-los, propõe-se uma interpretação evolutiva do texto constitucional.

\section{Alguns sentidos do vocábulo "poder" no bojo da Constituição Federal}

Carlos Ayres Britto, em estudo levado a efeito ainda sob a égide da Constituição de 1969, mas absolutamente aplicável à realidade atual, se ocupou de focalizar, em bases científicas, o sentido que se poderia extrair do termo poder tomando por base o corpo da Constituição Federal, ou seja, o ordenamento jurídico positivo, e não considerando o sentido metajurídico ou coloquial do termo ${ }^{27}$. De acordo com o entendimento do referido constitucionalista, o termo poder pode aparecer no texto constitucional pelo menos em quatro sentidos diferentes.

O primeiro sentido da palavra poder seria encontrado logo do parágrafo único do art. $1^{\circ}$ da $\mathrm{CF} / 88$, que estabelece que "Todo o poder emana do povo, que o exerce por meio de representantes eleitos ou diretamente, nos termos desta Constituição". O vocábulo poder, aí, está a significar "Poder

23 SILVA, José Afonso da. Curso de direito constitucional positivo. 22. ed. São Paulo: Malheiros, 2002, p. 85.

24 "Originário do direito inglês, o instituto [do impeachment] foi incorporado pelo direito brasileiro a partir da nossa primeira Constituição republicana (1891), sob inequívoca inspiração da Constituição dos Estados Unidos (1787), cujos Pais Fundadores reconheceram prontamente a possibilidade de abuso por parte daqueles que transitoriamente exercem o poder em nome do povo, especialmente do Presidente da República, e a necessidade de uma solução institucional (não apenas prevista pela Constituição, mas coerente com o princípio da separação e independência dos Poderes) para pôr fim a tais abusos". YOSHIKAWA, Eduardo Henrique de Oliveira. Do impeachment do Vice-Presidente da República. Revista dos Tribunais, ano 105, vol. 968, p. 104, jun. 2016.

25 Giuseppe Chiovenda, era peremptório ao afirmar que: “A teoria da divisão dos poderes, em suas primeiras aplicações em França, foi entendida em sentido rígido e mecânico: assim, a cada órgão deveria corresponder uma só função e lhe era defeso ingerir na atividade do outro, sequer para sindicá-la ou corrigi-la”. CHIOVENDA, Giuseppe. Instituições de direito processual civil. Tradução: J. Guimarães Menegale. 2. ed. São Paulo: Saraiva, 1965, vol. 2, p. 8. No mesmo sentido: CASTRO NUNES. Teoria e prática do Poder Judiciário. Rio de Janeiro: Forense, 1943, p. 3.

26 DIDIER JR. Fredie. Curso de Direito Processual Civil. Introdução ao direito processual civil, parte geral e processo de conhecimento. vol. 1. 17 ed. Bahia: Juspodivm, 2015, p. 164.

27 "Assim é que os tratados, monografias, manuais didáticos, ensaios e outros gêneros menores da literatura jurídica têm ministrado explicações para o significado do vocábulo, isolado ou sob a forma das locuções 'poder político', 'poderes do Estado', 'poder governamental' e expressões assemelhadas, mas sempre sob o referencial teórico a ser universalmente aceito. Noutro falar, referencial que se não destina a revelar aquele específico sentido em que o poder é utilizado na Constituição Política do Brasil”. BRITTO, Carlos Ayres. Os sentidos do vocábulo “poder” na Constituição brasileira. Revista de Direito Público, n. 61, p. 60, jan./mar. 1982. Também reconhecendo os vários significados do termo poder no texto constitucional: TEMER, Michel. Elementos de Direito Constitucional. 20. ed. São Paulo: Malheiros. 2005, p. 117-118. ROCHA, José de Albuquerque. Teoria Geral do Processo. 10. ed. São Paulo: Atlas, 2009, p. 61-62. 
Nacional" ou "Poder Constituinte", cuja expressão formal mais eminente é a própria Constituição da República ${ }^{28}$.

Nesse sentido, o poder seria anterior à constituição do Estado, e, logicamente, aos seus órgãos. A fonte primária desse poder seria o povo. Embora pertença ao povo, o Poder Constituinte é exercido pelos seus representantes; daí a diferença entre titularidade e exercício do Poder Constituinte.

De acordo com a lógica ora proposta, portanto, fazendo-se a substituição dos termos (poder = Poder Constituinte) ter-se-ia a seguinte construção para o referido parágrafo único do art. 1ํo da CF/88: "O Poder Constituinte emana do povo, que o exerce por meio de representantes eleitos ou diretamente, nos termos desta Constituição".

$\mathrm{O}$ art. $2^{\circ}$ da $\mathrm{CF} / 88$ já contemplaria um outro sentido para o vocábulo poder, diferente daquele "Poder Constituinte" ou "Poder Nacional", tal como fora tomado no parágrafo único do art. $1^{\circ}$. Eis o texto do dito art. $2^{\circ}$ : "São poderes da União, independentes e harmônicos entre si, o Legislativo, o Executivo e o Judiciário".

Nessa segunda concepção, tem-se que se está diante de um poder já constituído. A palavra poder, nesse contexto, é sinônimo de "Órgão do Estado", "Órgão Estatal", "Poder do Estado", de modo a representar o sistema de órgãos em que o Legislativo, o Executivo e o Judiciário se constituem, como partes estruturais ou necessariamente componenciais da pessoa jurídica União ${ }^{29}$.

No mesmo sentido é o magistério de Cândido Rangel Dinamarco, para quem, nos termos do art. $2^{\circ}$ da CF/88, o vocábulo poder "representa cada um dos setores nos quais se situam os agentes do Estado e entre os quais se reparte as competências segundo dispõe a Constituição”30.

A palavra poder, portanto, nesse contexto do art. $2^{\circ} \mathrm{da} \mathrm{CF} / 88$, é sinônimo de órgão do estado, de modo a representar o sistema de órgãos em que o Legislativo, o Executivo e o Judiciário se constituem ${ }^{31}$. Fazendo a substituição (poder = órgãos do Estado), portanto, ter-se-ia o seguinte: "São órgãos do Estado, independentes e harmônicos entre si, o Legislativo, o Executivo e o Judiciário".

Também é possível se encontrar no texto constitucional o vocábulo poder num terceiro sentido, como equivalente a Estado ou pessoa pública política de base territorial. O vocábulo poder, sobretudo quando constitutivo da locução "poder público", é também utilizado pela Constituição como equivalente a "Estado". Estado, diga-se, de modo compreensivo de qualquer um dos entes federativos.

É o caso do art. 194 da CF/88, que prevê: "A seguridade social compreende um conjunto integrado de ações de iniciativa dos Poderes Públicos e da sociedade, destinadas a assegurar os direitos relativos à saúde, à previdência e à assistência social”.

Efetuando-se a substituição do vocábulo poder constante do art. 194 da CF/88 (poder público = Estado), ter-se-ia a seguinte construção: "A seguridade social compreende um conjunto integrado de ações de iniciativa do Estado e da sociedade, destinadas a assegurar os direitos relativos à saúde, à previdência e à assistência social”.

Também assim o $\$ 8^{\circ}$ do art. 37, que prevê que "A autonomia gerencial, orçamentária e financeira dos órgãos e entidades da administração direta e indireta poderá ser ampliada mediante contrato, a ser firmado entre seus administradores e o poder público...”

Em um quarto sentido, a palavra poder aparece como sinônimo de função, faculdade de ação ou competência para agir em determinada faixa de atividade jurídica.

$\mathrm{O}$ art. 44 da $\mathrm{CF} / 88$, por exemplo, prevê que "O Poder Legislativo é exercido pelo Congresso Nacional, que se compõe da Câmara dos Deputados e do Senado Federal”. A expressão "Poder Legislativo", pelo menos nesse contexto, deve ser entendida não naquela acepção subjetiva de órgão da pessoa União,

28 BRITTO, Carlos Ayres. Os sentidos do vocábulo "poder" na Constituição brasileira. Revista de Direito Público, n. 61, p. 61, jan./mar. 1982.

29 Idem, ibidem, p. 61.

30 DINAMARCO, Cândido Rangel. Vocabulário do processo civil. 1. ed. São Paulo: Malheiros, 2014 , p. 198.

31 LENZA, Pedro. Direito constitucional esquematizado. 19. ed. São Paulo: Saraiva, 2015, p. 590. 
constante do art. $2^{\circ}$ da $\mathrm{CF} / 88$, mas no sentido objetivo de parcela ou fração de competência política, de caráter legiferante ${ }^{32}$. É dizer: a competência para legislar assiste ao Congresso Brasileiro, ou, ainda: "A função legislativa é exercida pelo Congresso Nacional”.

O mesmo ocorre com o art. 76, ao prescrever que "O Poder Executivo é exercido pelo Presidente da República, auxiliado pelos Ministros de Estado”. A expressão "Poder Executivo", nessa hipótese, representa a função executiva e não naquela acepção subjetiva de órgão da pessoa União.

A mesma lógica deve ser aplicada no tocante à expressão "Poder Judiciário", constante do art. 92 da CF/88, que se encontra assim vazado: "São órgãos do Poder Judiciário: I - o Supremo Tribunal Federal; I-A - o Conselho Nacional de Justiça; II - o Superior Tribunal de Justiça; II-A - o Tribunal Superior do Trabalho...”.

O legislador constituinte, ao estabelecer, no referido art. 92, que "São órgãos do Poder Judiciário...", não está a tratar do "Poder Judiciário" enquanto órgão da pessoa jurídica União. Está, na verdade, a elencar os órgãos do Poder Judiciário que exercem a função jurisdicional.

Trata-se, portanto, de um outro significado da palavra poder, compreendido como faculdade de ação ou competência para agir em determinada faixa de atividade jurídica. Dessa construção é possível dizer que “o 'órgão-Poder' exerce o 'poder-competência', dado que a palavra poder tanto pode referirse a qualquer dos três órgãos estruturais do Estado, quanto à capacidade ou facultas agendi de cada um deles" 33 .

Mas, afinal, qual o sentido que o termo poder deve assumir no art. $5^{-}$, XXXV, da CF/88, para que se possa efetivamente pensar em uma concepção mais funcional da jurisdição?

\section{Do poder judiciário à apreciação jurisdicional: por uma concepção funcional da jurisdição}

Quando o texto constitucional prevê, no art. 5º, XXXV, que "a lei não excluirá da apreciação do Poder Judiciário lesão ou ameaça a direito", tem-se que a melhor interpretação a ser dada é no sentido de que o termo poder, nesse caso, não quer significar órgão (Poder Judiciário), mas, sim, função, faculdade de ação ou competência para agir em determinada faixa de atividade jurídica.

Com efeito, os textos constitucionais devem ser interpretados evolutivamente. Novos sentidos devem ser atribuídos aos dispositivos da Constituição, considerando mudanças históricas e dados sociais supervenientes, inicialmente não cogitados pelo legislador constituinte ${ }^{34}$. Essa adaptação, naturalmente, pressupõe postura dinâmica do intérprete, que deve estar atento para que a Constituição continue dando respostas necessárias e adequadas às diferentes demandas e exigências sociais.

Veja-se que esse entendimento encaixa perfeitamente com a interpretação constitucionalmente adequada do princípio da separação de poderes (item 2). De fato, numa vertente contemporânea, o princípio da separação de poderes deve ser compreendido numa perspectiva de distribuição pragmática de funções entre órgãos estatais, com competências próprias, ou seja, como uma técnica de divisão de trabalho entre setores que desempenham atividades políticas.

Veja-se, também, que o entendimento ora apresentado está em sintonia fina com o sistema multiportas, adotado no Brasil, que admite a existência de vários meios integrados de resolução de controvérsias. A partir do momento que se assume a interpretação de que não se deve excluir da função jurisdicional lesão ou ameaça a direito, afasta-se a possibilidade ampla e ilimitada de acesso ao Poder Judiciário.

De se registrar, ainda como reforço de argumentação, que a interpretação proposta para o art. $5^{\circ}, \mathrm{XXXV}$, da CF/88, está em absoluta harmonia com o CPC. Enquanto o texto constitucional estabelece

32 LENZA, Pedro. Direito constitucional esquematizado. 19. ed. São Paulo: Saraiva, 2015, p. 590.

33 BRITTO, Carlos Ayres. Os sentidos do vocábulo "poder" na Constituição brasileira. Revista de Direito Público, n. 61, p. 63, jan./mar. 1982, com grifos no original.

34 BARROSO, Luís Roberto. Interpretação e aplicação da constituição. 6. ed. São Paulo: Saraiva, 2004 , p. 146. 
que "a lei não excluirá da apreciação do Poder Judiciário lesão ou ameaça a direito", o art. $3^{\circ}$ do CPC, prevê que "Não se excluirá da apreciação jurisdicional ameaça ou lesão a direito".

A sutil diferença entre o texto constitucional e aquela empregada pela codificação processual revela uma a realidade imposta pelo Estado contemporâneo: verificada uma lesão ou ameaça de lesão a direito, as partes têm a possibilidade de buscar a apreciação jurisdicional, independentemente de ser ela exercida pelo Poder Judiciário, por outros entes privados ou, quiçá, por órgãos estatais, ainda que não necessariamente vinculados à estrutura do Poder Judiciário. A função jurisdicional há - sim - de ser adequada.

Diante desse contexto, não parece acertado dizer que o art. $3^{\circ}$ do CPC se limita a reproduzir o texto constitucional ${ }^{35}$. Há ainda quem defenda que o legislador infraconstitucional tratou de densificar a proteção prevista na Constituição Federal ${ }^{36}$. O fato é que para além de prever o acesso ao Poder Judiciário, avança-se na direção do acesso à função jurisdicional adequada.

Quando o CPC, expressa e categoricamente, faz referência ao vocábulo apreciação jurisdicional, além de deixar claro que a jurisdição não é prestada somente por órgãos do Poder Judiciário - já que outros órgãos exercem a função jurisdicional -, o dispositivo afasta a possibilidade, ainda hoje vigorante, de controle ilimitado pelo Poder Judiciário, de toda e qualquer decisão. Trata-se, pois, de mudança paradigmática, que corrobora, repita-se, a ideia de que se deve buscar outras formas mais adequadas de resolução de controvérsias. Sobre o dispositivo constante do CPC, Fredie Didier Jr:

O caput do art. $3^{\circ}$ do CPC praticamente reproduziu o dispositivo constitucional. A única mudança digna de registro foi a troca de ‘apreciação do Poder Judiciário' por 'apreciação jurisdicional'. A mudança é correta, pois a jurisdição pode ser exercida fora do Poder Judiciário, com acontece no caso em que o Senado exerce jurisdição e na arbitragem ${ }^{37}$.

É oportuno mencionar que quando ainda tramitava o projeto de lei que visava instituir o CPC/2015, discutiu-se acerca da disposição do art. $3^{\circ}$, conforme noticia Bernardo Silva de Lima, que chegou a apresentar sugestões para alterar o dispositivo. Eis o relato do referido processualista:

Em um primeiro momento, sugerimos a alteração do texto para a seguinte redação: Art. $3^{\circ}$. Não se excluirá da apreciação jurisdicional do Poder Judiciário lesão ou ameaça a direito, ressalvados os litígios voluntariamente submetidos à solução arbitral, na forma da lei. A proposta pretendia esclarecer que o Poder Judiciário não era como se provou não ser - a única via de atuação do poder jurisdicional do Estado. Contudo, o prof. Fredie Didier Jr., tomando ciência da nossa sugestão, propôs um novo texto, mais simplificado e discreto, ao qual imediatamente aderi e, nesta oportunidade, defendo como proposta de alteração ao art. $3^{\circ}$ do Novo Código de Processo Civil [que veio a ser o texto ao final aprovado $]^{38}$.

É importante destacar que não se está a pretender fazer a leitura da Constituição Federal ou compreender seus institutos tomando por base o CPC. Muito ao contrário. Como é de todos sabido, os

35 LIMA, Bernardo Silva de. O art. $3^{\circ}$ do anteprojeto do Novo Código de Processo Civil: um choque contra a emancipação da arbitragem. Estudos em homenagem ao professor José Joaquim Calmon de Passos. In: DIDIER JR., Fredie; BASTOS, Antonio Adonias Aguiar. O projeto do Novo Código de Processo Civil. Bahia: JusPodivm, 2012, p. 167.

36 "Agora, importante a realização de uma leitura mais atenta do projetado artigo 3o do Código de Processo Civil, tendo em vista que densifica um pouco mais o atual direito de acesso do artigo $5^{\mathbf{o}}$, inciso XXXV, da Constituição Federal, alocando no texto processual a possibilidade da realização da arbitragem, do incentivo à solução consensual dos conflitos, mostrando, inclusive, alguns caminhos, como a conciliação e a mediação, assim também deixando em aberto novas modalidades, incentivando aos profissionais do Direito que estimulem os meios alternativos de resolução de conflitos”. JOBIM, Marco Félix; MACEDO, Elaine Harzheim. Das normas fundamentais do processo e o projeto de Novo Código de Processo Civil brasileiro - repetições e inovações. JOBIM, Marco Félix; MACEDO, Elaine Harzheim. Das normas fundamentais do processo e o projeto de Novo Código de Processo Civil brasileiro - repetições e inovações. Revista Brasileira de Direito Processual - RBDPro. Belo Horizonte, ano 23, n. 87, p. 5, jul./set. 2014.

37 DIDIER JR. Fredie. Curso de Direito Processual Civil. Introdução ao direito processual civil, parte geral e processo de conhecimento. vol. 1. 17ª ed. Bahia: Juspodivm, 2015, p. 177.

38 LIMA, Bernardo Silva de. O art. $3^{\circ}$ do anteprojeto do Novo Código de Processo Civil: um choque contra a emancipação da arbitragem. Estudos em homenagem ao professor José Joaquim Calmon de Passos. In: DIDIER JR., Fredie; BASTOS, Antonio Adonias Aguiar. O projeto do Novo Código de Processo Civil. Bahia: JusPodivm, 2012, p. 183. 
diplomas normativos devem ser compreendidos a partir do texto constitucional, sendo certo que é a Constituição Federal o centro normativo ${ }^{39}$ de todo o sistema jurídico. O direito processual civil, como não poderia deixar de ser, é indissociável do conjunto formado pelas normas e pelos valores consagrados

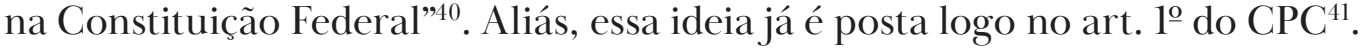

Como se disse, está a se propor uma interpretação evolutiva, que é aquela que deve ser realizada de modo a atribuir-se novos sentidos aos dispositivos da Constituição, sem, contudo, atentar contra sua essência, mas considerando mudanças históricas e dados políticos e sociais supervenientes, incialmente não cogitados pelo legislador constituinte.

A partir da interpretação apresentada no presente artigo, o princípio previsto no art. $5^{\circ}, \mathrm{XXXV}$, da $\mathrm{CF} / 88$ adquire uma feição prestacional, não uma simples garantia passiva, mas uma obrigação a ser ativamente ofertada pelo Estado, que deve considerar o aspecto da eficiência do serviço a ser ofertado à sociedade. Nesse sentido, longe de desmerecer ou mesmo diminuir a relevância do Poder Judiciário, tenciona-se é posicioná-lo em lugar merecido, como bem lembrava Calmon de Passos:

"Quando blateramos contra o modo pelo qual as coisas se passam, hoje, no Brasil, em termos de Poder Judiciário, não estamos enlameando este espaço da atividade pública, fundamental para a saúde democrática de qualquer povo, antes colocâmo-la em lugar privilegiado, fazendo-a objeto de nosso cuidado, porque desejamos vê-la livre de cair em tentação e liberta de todo o mal. Amém”"2.

\section{Referências}

BARROSO, Luís Roberto; BARCELLOS, Ana Paula. O começo da história. A nova interpretação constitucional e o papel dos princípios no direito brasileiro. Rio de Janeiro: Revista da EMERJ, n. 23, 2003.

BARROSO, Luís Roberto. Interpretação e aplicação da constituição. 6. ed. São Paulo: Saraiva, 2004.

BASTOS, Celso Ribeiro. Curso de Direito Constitucional, 18 ed. São Paulo: Saraiva, 1997.

BONAVIDES, Paulo; ANDRADE, Paes. História constitucional do Brasil. Rio de Janeiro: Paz e Terra, 1991.

BRITTO, Carlos Ayres. Os sentidos do vocábulo "poder" na Constituição brasileira. Revista de Direito Público, n. 61, jan./mar. 1982.

CARMONA, Carlos Alberto. A arbitragem no processo civil brasileiro. São Paulo: Malheiros, 1993.

CARNEIRO, Athos Gusmão. Jurisdição e competência. 15. ed. São Paulo: Saraiva, 2007.

CINTRA, Antonio Carlos de Araújo; DINAMARCO, Cândido Rangel; GRINOVER, Ada Pellegrini. Teoria geral do processo. 23 ed., São Paulo: Malheiros, 2007.

CHIOVENDA, Giuseppe. Instituições de direito processual civil. vol. 2. 2. ed. Tradução: J. Guimarães Menegale. São Paulo: Saraiva, 1965.

CUNHA, Leonardo José Carneiro da. Jurisdição e competência. São Paulo: Revista dos Tribunais, 2008.

DALLARI, Dalmo de Abreu. Elementos de teoria geral do Estado. 33. ed. São Paulo: Saraiva, 2016.

DANTAS, Ivo. Teoria geral do Estado. 3. ed. Curitiba: Juruá, 2016.

39 Sobre a força normativa da Constituição, conferir: HESSE, Konrad. A força normativa da Constituição. Tradução: Gilmar Ferreira Mendes. Porto Alegre: Sérgio Antonio Fabris Editor, 1991.

40 VIANA, Salomão. O projeto do novo CPC e o modelo de organização processual escolhido pelo legislador considerações sobre as normas fundamentais enunciadas nos arts. $2^{\circ}, 4^{\circ}, 5^{\circ}, 7^{\circ}, 8^{\circ}$ e $9^{\circ}$. In: FREIRE, Alexandre $e t$ al (coords.). Novas tendências do processo civil. Bahia: JusPodivm, 2014, v. 3, p. 635.

$41 \mathrm{CPC}$, art. $1^{\circ} \mathrm{O}$ processo civil será ordenado, disciplinado e interpretado conforme os valores e as normas fundamentais estabelecidos na Constituição da República Federativa do Brasil, observando-se as disposições deste Código.

42 PASSOS, J. J. Calmon de. Direito, poder, justiça e processo - julgando os que nos julgam. Rio de Janeiro: Forense, 2000, pág. 03 . 
DIDIER JR. Fredie. Curso de Direito Processual Civil. Introdução ao direito processual civil, parte geral e processo de conhecimento. vol. 1. 17 $\mathrm{a}$ ed. Bahia: Juspodivm, 2015.

DINAMARCO, Cândido Rangel. Vocabulário do processo civil. 1. ed. São Paulo: Malheiros, 2014. Instituições de direito processual civil. Vol. I, 8. ed, São Paulo: Malheiros, 2016.

GAJARDONI, Fernando da Fonseca. Aspectos fundamentais de processo arbitral e pontos de contato com a jurisdição estatal. Revista de Processo: São Paulo, n. 106, p. 190, jul. 2002.

GORDILLO, Agustin. Princípios gerais de direito público. São Paulo: Revista dos Tribunais, 1977.

HESSE, Konrad. A força normativa da Constituição. Tradução: Gilmar Ferreira Mendes. Porto Alegre: Sérgio Antonio Fabris Editor, 1991.

JOBIM, Marco Félix; MACEDO, Elaine Harzheim. Das normas fundamentais do processo e o projeto de Novo Código de Processo Civil brasileiro - repetições e inovações. Revista Brasileira de Direito Processual - RBDPro. Belo Horizonte, ano 23, n. 87, p. 5, jul./set. 2014.

KRELL, Andreas J. Leis de normas gerais, regulamentação do poder executivo e cooperação intergovernamental em tempos de reforma federativa. Belo Horizonte: Forum, 2008.

LENZA, Pedro. Direito constitucional esquematizado. 19 ed. São Paulo: Saraiva, 2015.

LIMA, Bernardo Silva de. O art. $3^{\circ}$ do anteprojeto do Novo Código de Processo Civil: um choque contra a emancipação da arbitragem. Estudos em homenagem ao professor José Joaquim Calmon de Passos. In: DIDIER JR., Fredie; BASTOS, Antonio Adonias Aguiar. O projeto do Novo Código de Processo Civil. Bahia: JusPodivm, 2012.

NETO, Zaidem Garaige. O princípio da inafastabilidade do controle jurisdicional, São Paulo: Revista dos Tribunais, 2006.

NERY JÚNIOR, Nelson. Princípios do processo na Constituição Federal. Processo civil, penal e administrativo. 11. ed. São Paulo: Revista dos Tribunais, 2013.

NUNES, Castro. Teoria e prática do Poder Judiciário. Rio de Janeiro: Forense, 1943.

OLIVEIRA, Carlos Alberto Alvaro de. Do formalismo no processo civil: proposta de um formalismovalorativo. 4. ed. São Paulo: Saraiva, 2010.

PASSOS, J. J. Calmon de. Direito, poder, justiça e processo - julgando os que nos julgam. Rio de Janeiro: Forense, 2000.

. A crise do Poder Judiciário e as reformas instrumentais: avanços e retrocessos. Revista Eletrônica sobre a Reforma do Estado. Bahia, n. 5, p. 01, março/abril/maio 2006. Disponível a partir de: $<$ http://www.direitodoestado.com.br $>$.

. Revisitando o Direito, o Poder, a Justiça e o Processo. Reflexões de um jurista que trafega na contramão. Bahia: JusPodivm, 2013.

ROCHA, José de Albuquerque. Teoria geral do processo. 10. ed. São Paulo: Atlas, 2009.

SANTOS, Moacyr Amaral. Primeiras linhas de direito processual civil. Processo de conhecimento, 25 ed. São Paulo: Saraiva, 2007.

SILVA, José Afonso da. Curso de direito constitucional positivo, 22. ed. São Paulo: Malheiros, 2002.

TEMER, Michel. Elementos de Direito Constitucional. 20. ed. São Paulo: Malheiros. 2005.

VIANA, Salomão. O projeto do novo CPC e o modelo de organização processual escolhido pelo legislador - considerações sobre as normas fundamentais enunciadas nos arts. $2^{\circ}, 4^{\mathrm{o}}, 5^{\mathrm{o}}, 7^{\mathrm{o}}$, $8^{\circ}$ e 9‥ In: FREIRE, Alexandre et al (coords.). Novas tendências do processo civil. Bahia: JusPodivm, 2014, v. 3.

YOSHIKAWA, Eduardo Henrique de Oliveira. Do impeachment do Vice-Presidente da República. Revista dos Tribunais, ano 105, vol. 968, p. 104, jun. 2016. 